\title{
Onset and development of the Iberian Poleward Flow in the Galician coast
}

\author{
R. Torres ${ }^{a, *}$ E.D. Barton ${ }^{b}$ \\ a Plymouth Marine Laboratory, Plymouth, U.K. \\ ${ }^{\mathrm{b}}$ Instituto de Investigaciones Marinas, Vigo, Spain
}

\begin{abstract}
Satellite, cruise and mooring observations in October and November 1999 have characterized the onset and development of the poleward flow along the Galician continental shelf and slope. Downwelling favourable winds during the cruise triggered the onset of the poleward flow. An offshore zonal temperature gradient, identifiable near $42^{\circ}$ in Sea Surface Temperature imagery, extended shorewards as coastal upwelling was suppressed by downwelling winds. Over the continental slope, the front turned more parallel to shore, as surface warm water was advected northward in the poleward flow. Downwelling winds increased mixing nearshore causing the pycnocline to intersect the upper slope to form a bottom front enhancing poleward geostrophic flow over the shelf. On the slope. a subsurface salinity maximum was associated with the poleward flow, becoming better defined as the poleward flow persisted. The flow was surface intensified and continuous to $650 \mathrm{~m}$ with characteristic speeds of 0.1 $\mathrm{ms}^{-1}$. The associated mean poleward transport was estimated at $2 \pm 0.5 \mathrm{~Sv}$. Direct transfer of momentum by the wind, elevation of sea level at the coast resulting from onshore Ekman transport, and the JEBAR mechanism all contribute towards the development of the poleward flow over the Galician shelf.
\end{abstract}

Key words: Iberia, Poleward Flow, downwelling winds, development

\section{Introduction}

Poleward flowing undercurrents are intrinsic to most upwelling systems (Neshyba et al., 1989) and the Galician upwelling system is no exception. Along-slope variability in wind stress forcing or topography can be called upon to explain its presence in the face of upwelling favourable winds ( Wang,

* Plymouth Marine Laboratory, Plymouth, U.K. 
1997; Trowbridge et al., 1998). However, the Galician upwelling regime is only present for part of the year (June-October). The rest of the year, a downwelling regime with a surface poleward flow settles in the shelf, and in the absence of upwelling, other forcings drive the slope poleward flow. Northward winds represent a possible mechanism except they are highly variable (Torres et al., 2003). They are more likely to contribute to the short temporal variability associated with the poleward flow, while an oceanic pressure gradient is responsible for its seasonal onset (Frouin et al., 1990; Haynes and Barton, 1990). Steady-state adjustment of an alongshore oceanic pressure gradient adjacent to a steep continental slope would fail to penetrate the shelf (Wang, 1982) as described in terms of the arrested topographic wave model of Csanady (1978). Shelf-ocean adjustment is confined to the slope region and results in a poleward slope-trapped current on eastern boundaries (Hill et al., 1998). Huthnance (1984, 1995) described the JEBAR effect (joint effect of baroclinicity and relief), assuming the oceanic sea-level gradient is physically due to the meridional drop in steric height arising from the fall in oceanic temperatures poleward. Zonally oriented density surfaces intersect a meridional sloping boundary and a dynamical adjustment of the density-induced pressure gradient to the bottom slope takes place. The JEBAR effect should apply along the entire eastern boundary but is most relevant upstream of regions where steric height drops markedly. A meridional density gradient is maximum between $39^{\circ} \mathrm{N}$ and $41^{\circ} \mathrm{N}$ (Arhan et al., 1994) but weakens/disappears northwards. At $43^{\circ} \mathrm{N}$, the coastline becomes zonal and the JEBAR mechanism no longer forces the poleward flow directly. Considering frictional effects in the absence of direct forcing, Pingree and LeCann (1990) showed that the JEBAR-induced poleward flow decays with a length scale smaller than the northern Spanish coast, and hence propagates along the slope away from the source reaching the French coast of the Bay of Biscay. Temporally varying spatial structures in the California undercurrent have been related to the interaction of the current with the complex topography (Noble and Ramp, 2000), but the relevance of this in the Galician region remains to be assessed.

In this paper, results of a cruise to study the physical structure and biological functioning of the Iberian Poleward flow are reported. The present data set provides one of the most detailed samplings of the onset of the poleward flow around the Galician coast available to date. The structure of the flow regime was measured directly for the first time, elucidating its relation to the typical warm surface anomaly, sub-surface salinity maximum and other hydrographical signatures of the northward current. 
(a)

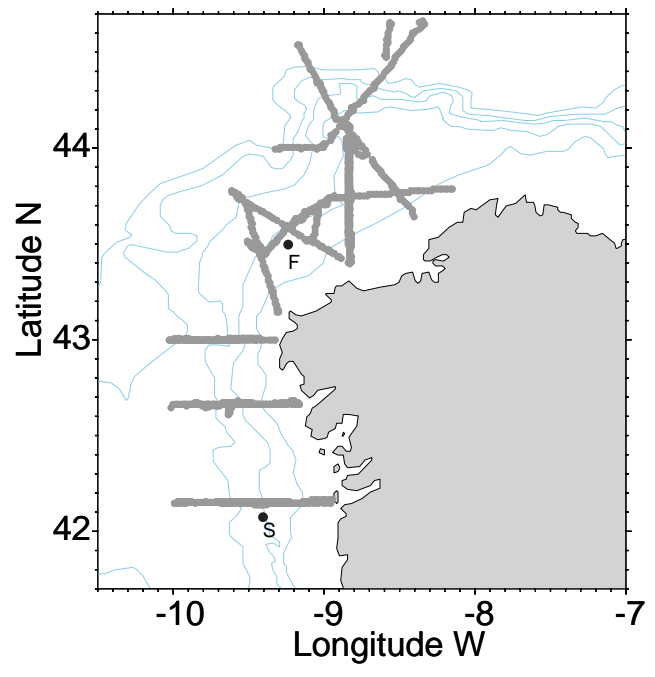

(b)



Fig. 1. (a) ADCP transects and (b) CTD stations positions visited during the THAL99 cruise (13 October-7 November 1999). Black diamonds mark the fresh water sources along the Galician coast. Buoys S and F are also labelled.

\section{Data and methods}

The data presented here were largely collected during 13 October-7 November 1999 cruise on board the R/V Thalassa in the Galician region. Nearshore transects and CTD stations occupied during the entire cruise can be seen in Fig. 1.

A total of 120 CTD drops was made with a Neil Brown Systems Mk IIIB CTD measuring temperature, conductivity, pressure and fluorescence. Casts were made to $500 \mathrm{~m}$ depth or the sea bed where shallower. On several occasions, transects of the top $100 \mathrm{~m}$ were sampled with a towed undulating CTD, the Aquashuttle Undulating Oceanographic Recorder (UOR) from Chelsea Instruments measuring temperature, salinity, depth and fluorescence. The typical depth range during the cruise was $30-100 \mathrm{~m}$ at a towing speed of $8 \mathrm{kt}$.

Underway measurements of temperature, salinity and fluorescence were taken every 10min with a SeaBird 21 Thermosalinometer from the continuous water supply from a nominal depth of $5 \mathrm{~m}$.

CTD transect plots were built through Barnes interpolation with $10 \mathrm{~m}$ and $15 \mathrm{~km}$ scales in the vertical and horizontal respectively. We have used distance from the shelf edge, as identified from the ADCP signal, with positive values offshore from the shelf as the horizontal gridding variable. Raw surface salinity and temperature from the Thermosalinometer are also shown to enable assessment of the smoothing applied by the interpolation. 
The Thalassa is equipped with two RDI ADCP that were used simultaneously during the cruise. Both the $150 \mathrm{Khz}$ broadband (BB) and $75 \mathrm{Khz}$ narrowband (NB) performed relatively well in spite of bad weather. The set up of the ADCP systems, both installed at $6 \mathrm{~m}$ depth, is summarized in Table 1.

\begin{tabular}{cccccccc}
\hline \hline \multicolumn{7}{c}{ Characteristics of ADCP system setup } \\
\hline \\
$\begin{array}{ccccccc}\text { Cell } \\
\text { length }\end{array}$ & $\begin{array}{c}\text { Pulse } \\
\text { length }\end{array}$ & $\begin{array}{c}\text { Blanking } \\
\text { interval }\end{array}$ & $\begin{array}{c}\text { No of } \\
\text { bins }\end{array}$ & $\begin{array}{c}\text { Pings per } \\
\text { ensemble }\end{array}$ & $\begin{array}{c}\text { Averaging } \\
\text { interval }\end{array}$ & $\begin{array}{c}\text { Pitch \& roll } \\
\text { compensation }\end{array}$ \\
\hline $75 \mathrm{Khz}$ & $16 \mathrm{~m}$ & $16 \mathrm{~m}$ & $16 \mathrm{~m}$ & 50 & 4 & $300 \mathrm{~s}$ & No \\
$150 \mathrm{Khz}$ & $8 \mathrm{~m}$ & $8 \mathrm{~m}$ & $8 \mathrm{~m}$ & 50 & 1 & $300 \mathrm{~s}$ & No \\
\hline \hline Table 1
\end{tabular}

Table 1

Configuration setup for cruise Thal99

The processing of both datasets followed the technique described in Torres and Barton (1999). The percentage of good bins processed by both ADCPs was high during most of the cruise $(>80 \%)$ except at times of rough weather. Good data were obtained typically to $500 \mathrm{~m}$ for the NB ADCP and $250 \mathrm{~m}$ for the BB ADCP. No data are used below these depths. The BB ADCP showed poorer data quality when the ship was sailing against the predominant sea as it was closer to the prow than the NB ADCP.

The calibration of both systems used the water track method. Amplitude and phase estimation was done by averaging 190 and 182 points for the NB and $\mathrm{BB}$ ADCP respectively. The amplitude and misalignment angle used in the correction are shown in Table 2 together with their standard deviation. The largest associated uncertainties in calibration parameters come from the standard deviation of the phase misalignment angle which could introduce spurious speeds of up to $7 \mathrm{cms}^{-1}$ at a highest ship speed of $\sim 5 \mathrm{~ms}^{-1}$.

Table 2

\begin{tabular}{ccccc}
\hline \hline & \multicolumn{2}{c}{$\beta \pm \sigma$} & \multicolumn{2}{c}{$\alpha \pm \sigma$} \\
\hline $75 \mathrm{Khz}$ & 0.98 & \pm 0.01 & 0.2 & \pm 0.8 \\
$150 \mathrm{Khz}$ & 0.99 & \pm 0.01 & 0.9 & \pm 0.8 \\
\hline \hline
\end{tabular}

Calibration parameters for THAL99

Linear comparison between the two systems during a three day drifting experiment showed good agreement. In general, the NB measured greater velocities than the $\mathrm{BB}$, by $6 \%$ and $13 \%$ on the $\mathrm{U}$ and $\mathrm{V}$ components. Considering the difference in depth resolution and the $2 \mathrm{~min}$ offset between the two ADCPs, both systems agree well.

The north and east velocity components were rotated into along and across-shelf components. The choice of a local along-shelf direction is difficult, particularly in an area of such complex bathymetry. Uncertainties in the along-shelf 
direction have an important effect on the across-shore component, which should be interpreted with caution. When repetitions of ADCP transects exist, mean sections of the along and across-shelf velocity components have been built in an attempt to reduce the tidal signal. More effective and complex methods exist for reducing the tidal signal in shipboard ADCP records (e.g. Candela et al., 1992; Howarth and Proctor, 1992; Münchow, 2000) but the availability of repeated sections and the strength of the offshore residual currents (e.g. $\left.\sim 15-20 \mathrm{cms}^{-1}\right)$ in comparison to the tidal flow $\left(\sim 8 \mathrm{cms}^{-1}\right.$, Fanjul et al., 1997) allowed us to use the simplest method.

In situ wind observations were collected between 1 October and 30 November 1999 by 2 buoys moored near the Galician shelf break (Fig. 1)as part of the Spanish Puertos del Estado Deep Water Network. Their positions were $43^{\circ} 29.4^{\prime} \mathrm{N}, 9^{\circ} 12.6^{\prime} \mathrm{W}$ in $382 \mathrm{~m}$ off cape Finisterre and at $42^{\circ} 6^{\prime} \mathrm{N}, 9^{\circ} 23.2^{\prime} \mathrm{W}$ in $323 \mathrm{~m}$ depth. In the text we refer to them as $\mathrm{F}$ and $\mathrm{S}$ buoys, respectively. The buoys also measured currents at 3m depth with an UCM60 acoustic current meter. The data were measured hourly and filtered with a moving average filter A24A24A25 (Godin, 1991) with a cutoff frequency of 30 hours to remove tides and inertial components.

SST from Advanced Very High Resolution Radiometer (AVHRR) for the same period and area were processed at Plymouth Marine Laboratory using the Panorama software (Miller et al., 1997).

\section{Results}

\subsection{Background and evolution}

Weekly composites of SST (Fig. 2) show the warm anomaly related to the poleward flow developing mid-cruise and strengthening towards its end. A general decrease of $1.5^{\circ} \mathrm{C}$ in $\mathrm{SST}$ is apparent in the sequence. A zonal SST front of $1^{\circ} \mathrm{C}$ contrast and $40 \mathrm{~km}$ wide is present in all images, centred at $42^{\circ}$. During the week prior to the cruise, evidence of remnant coastal upwelling can be seen on the west coast and north of Cape Finisterre (Fig. 2a). Moderate poleward winds on 14-18 October (see Fig. 3a-b) narrowed the coastal band of upwelled water while a warm intrusion of SST moved northwards along the $1000 \mathrm{~m}$ isobath north of $42^{\circ}$ (Fig. 2b). Northward winds strengthened on 19-23 October and the coastal upwelled water disappeared from both coasts (Fig. 2c). The warm intrusion $\left(1^{\circ}\right.$ warmer than surrounding water on the west coast) became better defined, its core located between the $200 \mathrm{~m}$ and $1000 \mathrm{~m}$ isobath off the west coast. After rounding Cape Finisterre the intrusion weakened (temperature anomaly of $0.5^{\circ} \mathrm{C}$ ) and moved closer to the coast. Short 

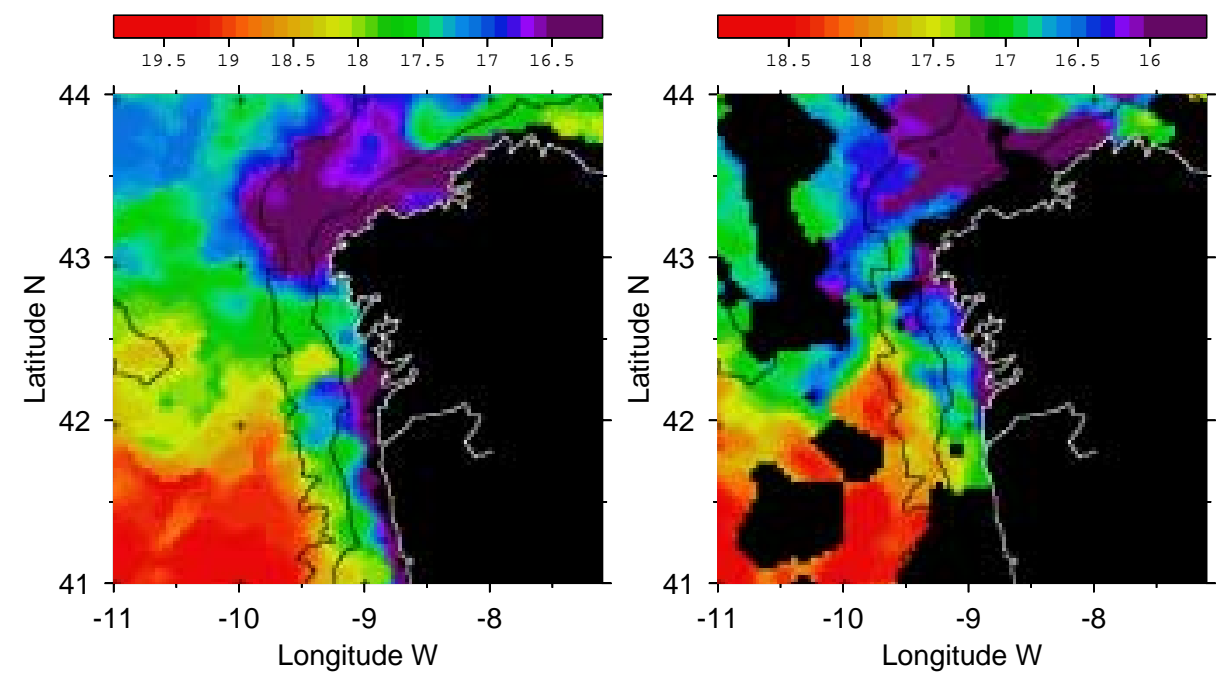

(a) Oct $10-16$

(b) Oct 17-23
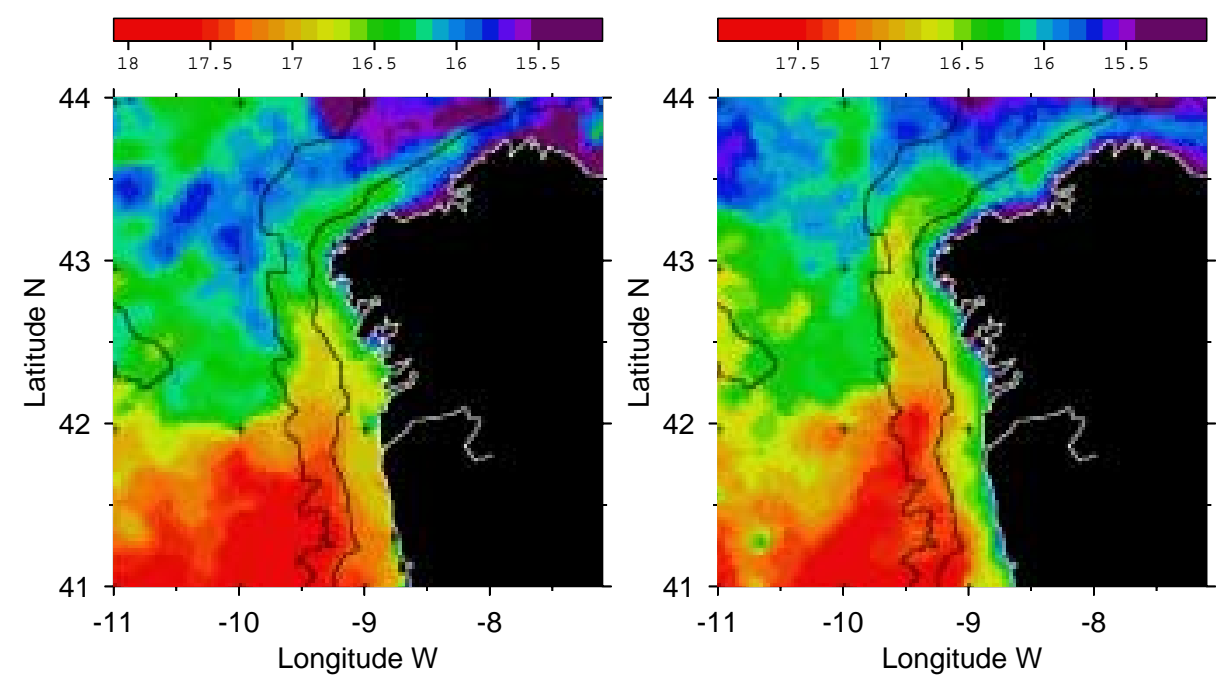

(c) Oct 24-30

(d) Oct 31- Nov 6

Fig. 2. Weekly SST composites during the THAL99 cruise (13 October-7 November 1999). Clouds and land are masked as black. 
(a)



(c)



(b)

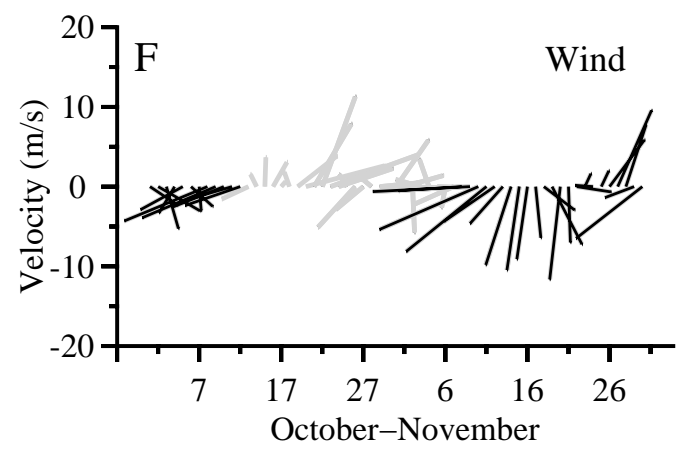

(d)



Fig. 3. Wind (a-b) and Current (c-d) vectors measured at buoys a,c) S and b,d) F (1 October- 30 November). Light gray corresponds to the cruise period. North is aligned to the positive y axis.

upwelling favourable wind pulses on 26-27 October and 2-3 November could have been responsible for the narrow band of cold water close to the west coast (Fig. 2d). However the warm poleward intrusion strengthened, with the $1^{\circ} \mathrm{C}$ anomaly reaching Cape Finisterre. North of the cape, the intrusion became wider and continued along the coast the following week (not shown) despite upwelling favourable winds (Figs. 3).

Daily medians of hourly winds from buoys $\mathrm{S}$ and $\mathrm{F}$ from 1 October-30 November (Fig. 3a-b) are representative of the larger scale winds measured by the Seawinds instrument on the QuikScat satellite ((Torres et al., 2003)). Winds during the cruise were weak and SE until 15 October, then strengthened $\left(\sim 13 \mathrm{~ms}^{-1}\right)$ and became more SW and W by 23 October. For the remainder of the cruise they alternated between brief pulses of upwelling and downwelling favourable conditions.

At S, sub-tidal surface currents (Fig. 3c-d), southwards at the beginning of the record, rotated clockwise to become mainly poleward from 10 October to 7 November. Winds reverted to upwelling-favourable after 7 November but currents remained poleward with a small offshore component. At F, currents were stronger but followed the same evolution as at S. The difference in orientation of the poleward flow is related to a change of $40^{\circ} \mathrm{E}$ in the coast 
orientation between sites $\mathrm{S}$ and $\mathrm{F}$. The only other difference was the earlier onset of poleward currents and near reversal of currents on 8-18 November at F.

Summarizing, the THAL99 cruise took place during the onset of the winter poleward flow regime at the end of a weak summer upwelling regime, when persistent poleward flow started to develop. In the remainder of the article, data will be presented in two sections, the west coast sampling from 13-21 October which can be related to the first stages of the poleward flow development seen at the buoys; and the north coast sampling, during which the poleward flow was steadier and stronger and had reached north of Cape Finisterre. 


\begin{tabular}{|c|c|c|c|c|c|}
\hline Transect & Instrument & St. Time & End Time & St. Position & End Position \\
\hline \multirow[t]{2}{*}{ S } & CTD & $14 / 1015: 22$ & 15/10 20:07 & $9^{\circ} 59-42^{\circ} 09$ & $8^{\circ} 57-42^{\circ} 08$ \\
\hline & & $14 / 1015: 38$ & $15 / 1013: 57$ & $9^{\circ} 59-42^{\circ} 09$ & $8^{\circ} 58-42^{\circ} 08$ \\
\hline \multirow[t]{3}{*}{ S } & $\mathrm{ADCP}$ & $15 / 1022: 12$ & 16/10 02:19 & $9^{\circ} 12-42^{\circ} 09$ & $10^{\circ} 00-42^{\circ} 09$ \\
\hline & & $16 / 1002: 27$ & 16/10 07:07 & $9^{\circ} 58-42^{\circ} 09$ & $9^{\circ} 8-42^{\circ} 08$ \\
\hline & CTD & $16 / 1014: 56$ & $17 / 1014: 37$ & $10^{\circ} 00-42^{\circ} 40$ & $9^{\circ} 12-42^{\circ} 40$ \\
\hline \multirow[t]{4}{*}{$\mathrm{P}$} & $\mathrm{ADCP}$ & $16 / 1015: 57$ & $17 / 1014: 17$ & $10^{\circ} 00-42^{\circ} 39$ & $9^{\circ} 14-42^{\circ} 40$ \\
\hline & & $18 / 1002: 43$ & 18/10 06:53 & $9^{\circ} 57-42^{\circ} 40$ & $9^{\circ} 13-42^{\circ} 40$ \\
\hline & CTD & 18/10 14:06 & $19 / 1011: 41$ & $10^{\circ} 01-43^{\circ} 00$ & $9^{\circ} 18-43^{\circ} 00$ \\
\hline & & $18 / 1015: 27$ & 18/10 21:06 & $9^{\circ} 59-43^{\circ} 00$ & $9^{\circ} 24-43^{\circ} 00$ \\
\hline \multirow[t]{4}{*}{$\mathrm{N}$} & $\mathrm{ADCP}$ & 18/10 22:08 & 19/10 01:35 & $9^{\circ} 25-43^{\circ} 00$ & $10^{\circ} 01-43^{\circ} 00$ \\
\hline & & 19/10 01:43 & 19/10 07:23 & $10^{\circ} 01-43^{\circ} 00$ & $9^{\circ} 24-43^{\circ} 00$ \\
\hline & UOR & $18 / 1022: 45$ & 19/10 01:35 & $9^{\circ} 25-43^{\circ} 00$ & $10^{\circ} 01-43^{\circ} 00$ \\
\hline & CTD & 25/10 9:54 & $26 / 105: 30$ & $8^{\circ} 22-43^{\circ} 35$ & $9^{\circ} 10-44^{\circ} 32$ \\
\hline \multirow[t]{3}{*}{ PW1 } & & $21 / 1010: 25$ & $21 / 1023: 52$ & $8^{\circ} 27-43^{\circ} 34$ & $9^{\circ} 30-44^{\circ} 55$ \\
\hline & $\mathrm{ADCP}$ & $22 / 1003: 12$ & $22 / 1014: 13$ & $9^{\circ} 29-44^{\circ} 54$ & $7^{\circ} 56-43^{\circ} 50$ \\
\hline & & 25/10 09:40 & $26 / 10$ 05:58 & $8^{\circ} 25-43^{\circ} 40$ & $9^{\circ} 10-44^{\circ} 32$ \\
\hline \multirow[t]{3}{*}{ PW2 } & CTD & $31 / 10 \quad 8: 12$ & $31 / 1022: 06$ & $8^{\circ} 50-44^{\circ} 00$ & $8^{\circ} 50-43^{\circ} 24$ \\
\hline & $\mathrm{ADCP}$ & $31 / 10 \quad 09: 39$ & $31 / 1022: 59$ & $8^{\circ} 50-44^{\circ} 01$ & $8^{\circ} 50-43^{\circ} 24$ \\
\hline & & $31 / 10$ 23:09 & 01/11 04:46 & $8^{\circ} 49-43^{\circ} 24$ & $8^{\circ} 50-44^{\circ} 07$ \\
\hline PW3 & $\mathrm{CTD} / \mathrm{ADCP}$ & 01/11 11:48 & 01/11 22:47 & $8^{\circ} 49-43^{\circ} 24$ & $9^{\circ} 30-43^{\circ} 42$ \\
\hline PW4 & $\mathrm{CTD} / \mathrm{ADCP}$ & 02/11 8:17 & 02/11 19:58 & $9^{\circ} 31-43^{\circ} 42$ & $9^{\circ} 18-43^{\circ} 08$ \\
\hline
\end{tabular}

Table 3

Time, location and instrument of the transects sampled during cruise Thal99.

\subsection{The west coast}

Three transects, S, P and N, were sampled, (Fig. 1) with CTD and ADCP once, and repeated at least one more time with only ADCP or, on occasions, ADCP and UOR. Transect details are summarised in Table 3.

Transect $\mathrm{S}$ showed surface salinity and temperature values of $35.3 \mathrm{psu}$ and $17.2^{\circ}-17.5^{\circ} \mathrm{C}$ (Fig. 4a-b) extending from nearshore to $13 \mathrm{~km}$ from the shelf edge. Offshore, surface temperature and salinity values increased to $18.7^{\circ} \mathrm{C}$ and $35.75 \mathrm{psu}$ at a sharp surface layer front of $\sim 5 \mathrm{~km}$ (Figs. 4a-b). A weak 
temperature maximum centered around $40 \mathrm{~km}$ was also apparent. The spike in temperature and salinity located around $5 \mathrm{~km}$ is an artefact resulting from an interruption in the sampling, during which time the front moved shoreward.

Over the shelf, the lower salinity surface layer was 50m thick (Figs. 4c) and had high fluorescence levels (Fig. 4e) indicative of a freshwater origin. Nonetheless, the slight coastal uplifting of isolines of salinity, temperature and density provides evidence of weak coastal upwelling. The surface front also marked a transition from a surface fluorescence maximum inshore to a sub-surface one around $50 \mathrm{~m}$ offshore depth (Figs. 4e). This deep fluorescence maximum was related to the shoreward intrusion of offshore warm surface waters, measured at buoy $\mathrm{S}$ on 14 October (Fig 3c). This idea is supported by the association of the sub-surface fluorescence maximum with relatively low salinity values at 40-50m (Fig 4c).

A sub-surface salinity maximum (>35.9psu) was measured at $65-110 \mathrm{~m}$ depth, $0-35 \mathrm{~km}$ off the shelf, and in association with a localised weakening of the thermocline and pycnocline (Fig 4d). At that depth, isopycnals (e.g $27.1 \mathrm{~kg}$ m-3) deepened towards the coast, consistent with poleward geostrophic flow (Fig 4f). Below 400m, higher salinity appeared in relation to the northward advection of Mediterranean water within $30 \mathrm{~km}$ of the shelf. The wide spacing of the stations prevents a precise estimate of the offshore limit of the sub-surface intrusion although some indication can be gained from the more densely spaced ADCP data.

During the ADCP repeat surveys, the surface salinity and temperature front (Fig. 5a-b) moved $10 \mathrm{~km}$ shoreward. Also, the surface temperature maximum (temperature anomaly of $\sim 0.5^{\circ} \mathrm{C}$ )) intensified and moved shorewards to $20-30 \mathrm{~km}$ from the shelf edge (WA in Fig. 5b). The across-shelf component (Fig. 5c) was small and mainly onshore, except for a deep offshore flowing core centred at $200-400 \mathrm{~m}$ at $30 \mathrm{~km}$ off the slope. Two northward flowing cores off the shelf (Fig. 5d) reached speeds of $15-10 \mathrm{cms}^{-1}$, coincident with minima in the standard deviation ( $\sigma<5 \mathrm{cms}^{-1}$ not shown). The shallower, at $50-120 \mathrm{~m}$ depth, was $10 \mathrm{~km}$ offshore of the surface temperature maximum (Fig. 5b) in the last two repetitions of the transect but coincides with the mean position of WA. It also corresponded with the interpolated offshore limit of the sub-surface salinity maximum in Fig. 4c. The deeper core appeared to shift shorewards with respect to the shallower one and may be related to the Mediterranean water upper core (typically located at 700m Fiúza et al., 1998) through vertical transfer of momentum. Weaker northward flow occurred over the shelf edge down to at least $180 \mathrm{~m}$ depth.

Transect $\mathrm{P}$ showed similar characteristics to transect $\mathrm{S}$ and therefore is not shown. Transect N (Fig 6) displayed some differences with the previous two, although it again had: a warm surface intrusion associated with low 
(a)

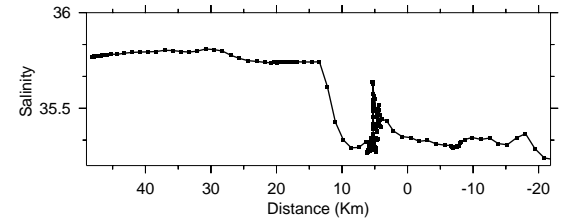

(c)

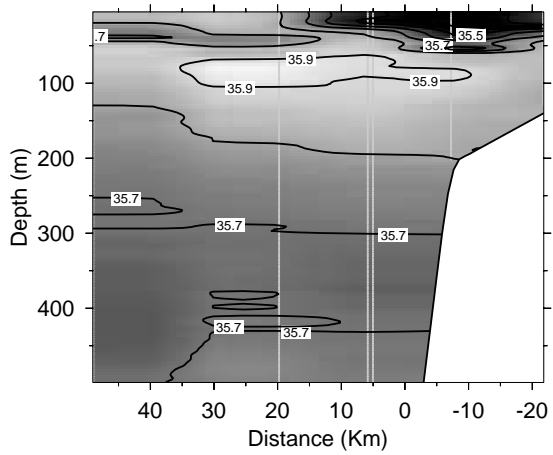

(e)

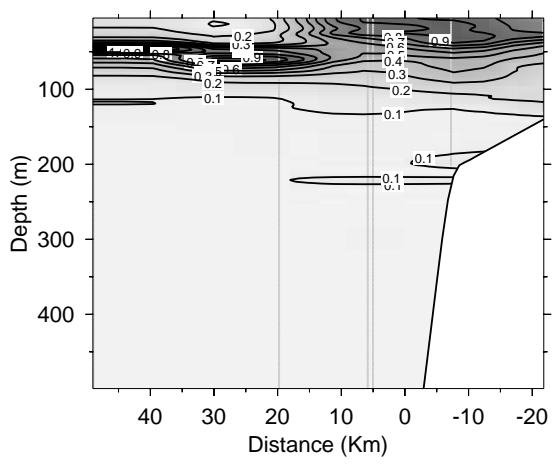

(b)

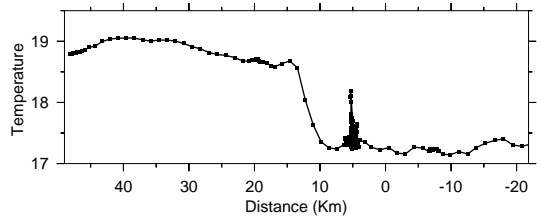

(d)

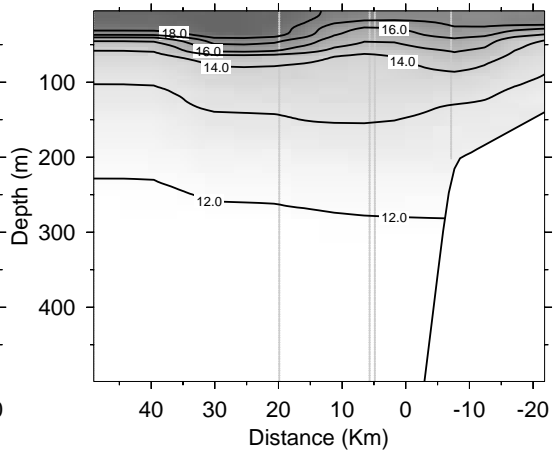

(f)

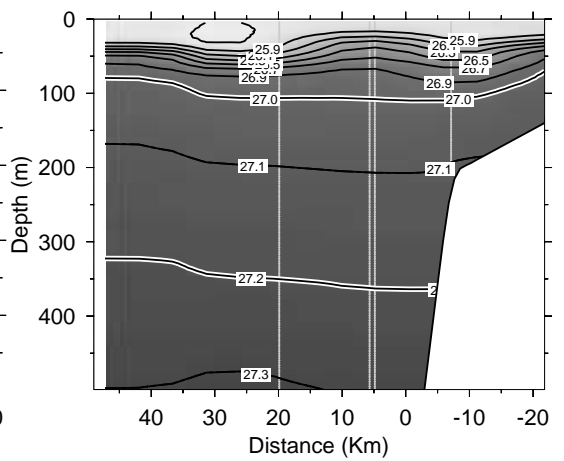

Fig. 4. Transect S CTD sections (14-15 October) for a) surface salinity, b)surface temperature, and vertical sections of c) salinity, d) temperature, e) fluorescence and f) density.

fluorescence values, a sub-surface salinity maximum at $100 \mathrm{~m}$ off shelf, and low salinity waters associated with freshwater runoff on the shelf. However, the surface signature of the offshore warm and salty intrusion (Fig 6a-b) was less well defined than in transects $\mathrm{S}$ or $\mathrm{P}$, and the colder and fresher shelf waters formed a weaker shelf break front than in transect S. Freshwater runoff on the shelf formed a thicker $(50 \mathrm{~m})$ and narrower layer than in the more southern transects, but still reached the shelf edge. As in transect $\mathrm{P}$, the isotherms and isopycnals between $30-200 \mathrm{~m}$ separated vertically over the outer shelf (Fig 6d,f), where higher bottom fluorescence values than transect S (Fig 6e) suggested sinking along the shelf bottom and the suppression of the earlier weak upwelling by strengthening poleward winds. There is some indication of the separation of the sub-surface salinity maxima into two cores, 
(a)

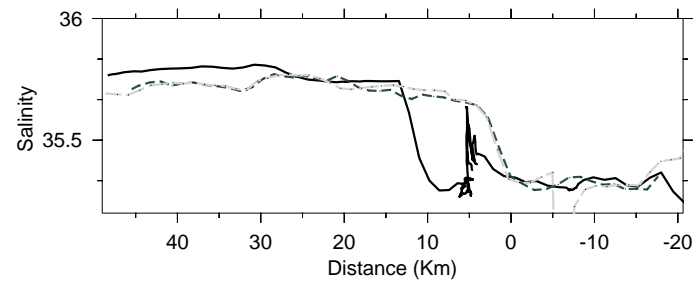

(c)



(b)

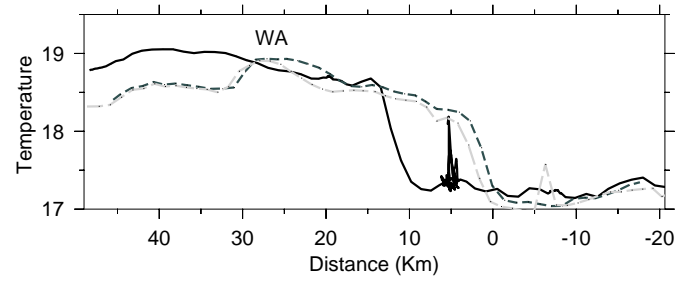

(d)

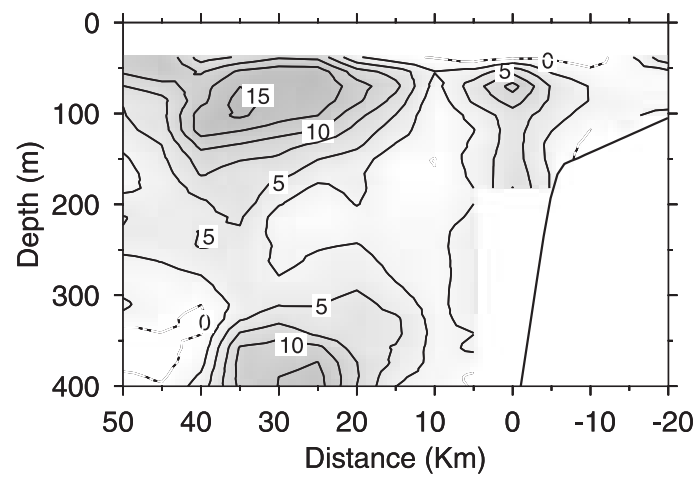

Fig. 5. Surface a) salinity and b) temperature coincident with the ADCP sections (lighter dashed line indicates later crossing) for transect $\mathrm{S}$. The developing warm anomaly (WA) is labelled. NB ADCP averaged sections, c) across-shelf component (+ve onshore) and d) along-shelf component (+ve alongshore). The coast local direction is $21.1^{\circ} \mathrm{E}$.

one on the shelf and one offshore(Fig 6b).

The evolution of the surface salinity and temperature (Fig. 7a-b) during subsequent repetitions of transect $\mathrm{N}$ showed an enhancement of the warm intrusion temperature signature but little shoreward displacement, in contrast with previous transects. The velocity structure of the averaged section showed offshore flow west of $20 \mathrm{~km}$ (Fig. 7c) with negligible associated along shelf component while poleward flow (Fig. 7d) was associated with zero or very weak onshore flow. The strongest barotropic poleward flow was measured on the inner shelf associated with low salinity $\left(>15 \mathrm{cms}^{-1}\right.$ in both ADCPs). Off the shelf, two cores of poleward flow occurred as in transect $S$ although they were weaker. The shallower core had peak velocities of $\sim 6-7 \mathrm{cms}^{-1}$ extending from the first bin to $200 \mathrm{~m}$ depth at $30 \mathrm{~km}$ off the shelf. The deeper core had velocities in excess of $7 \mathrm{cms}^{-1}$ at $300 \mathrm{~m}$ depth, $20 \mathrm{~km}$ off the shelf. Overall maximum velocities off the shelf were weaker and closer to the shelf break than in transect $\mathrm{S}$.

The second repetition of transect $\mathrm{N}$ (Fig. 7) with UOR and BB ADCP shows the detailed vertical structure of the warm intrusion (Fig. 8). Numerous vertical fluctuations at the thermocline (larger than $15 \mathrm{~m}$ ) indicate the energetic internal wave activity of the region (Barton et al., 2001). The 
(a)

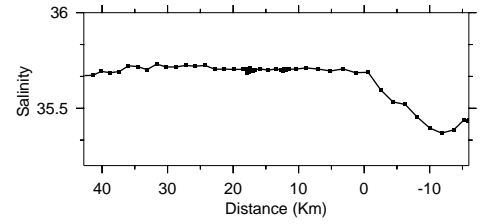

(c)

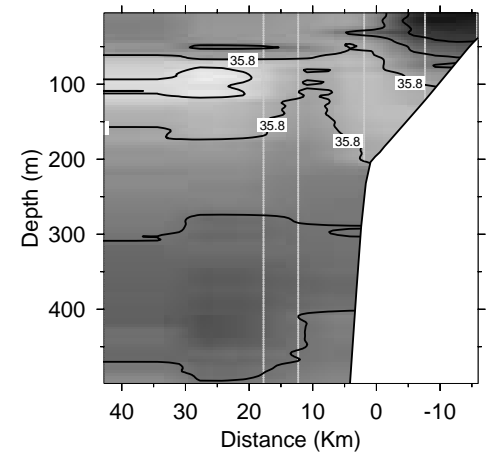

(e)

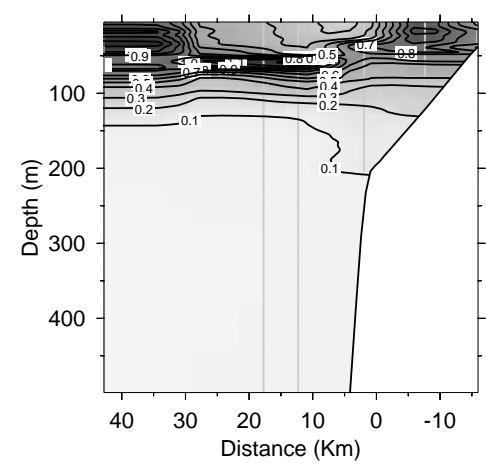

(b)

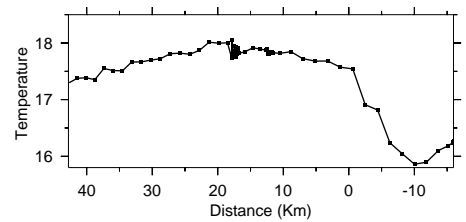

(d)

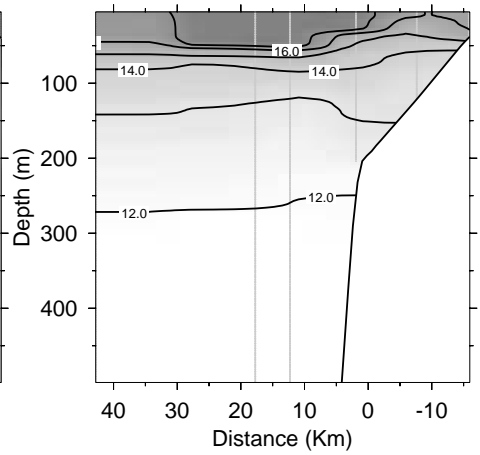

(f)

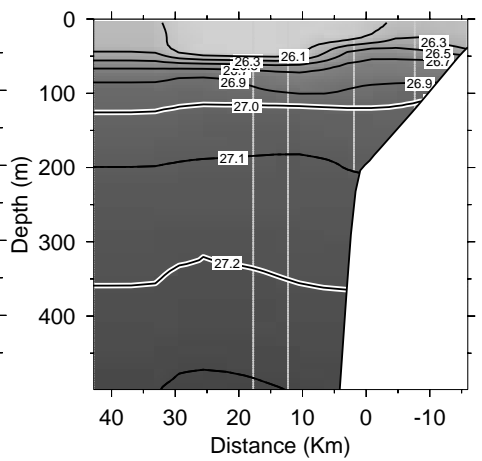

Fig. 6. Transect N CTD sections (18-19 October) for a) surface salinity, b)surface temperature, and vertical sections of c) salinity, d) temperature, e) fluorescence and f) density.

intrusion was very shallow, affecting mainly the top $50 \mathrm{~m}$, and is characterised by a widened thermocline (Fig. $8 \mathrm{a})$. The narrow core $(\sim 20 \mathrm{~km})$ had temperatures in excess of $17.5^{\circ} \mathrm{C}$ in agreement with the surface records in Fig. 7b. The velocity structure in Fig. 7b largely reflected northward flow in the thermal anomaly. Maximum speeds in the strongly baroclinic flow were associated with the offshore limit of the intrusion, and flow was near zero at its nearshore end. 
(a)

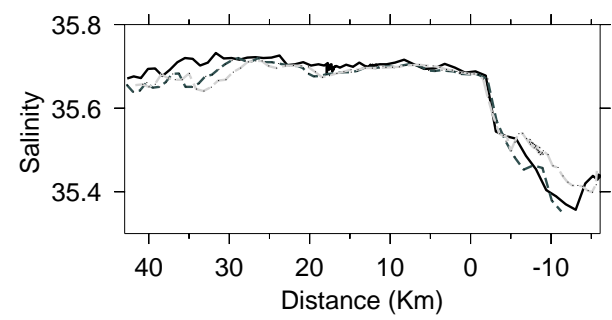

(c)

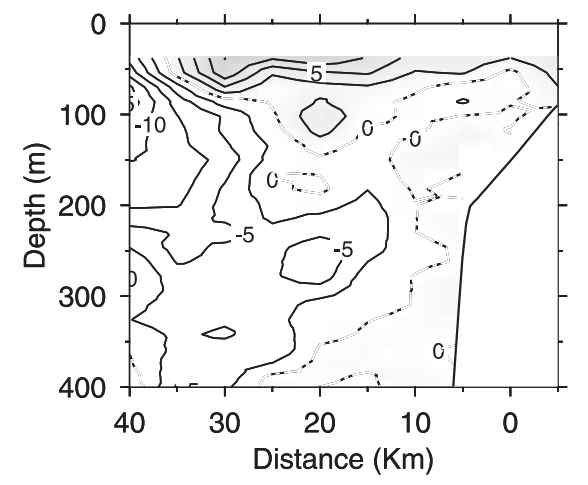

(b)

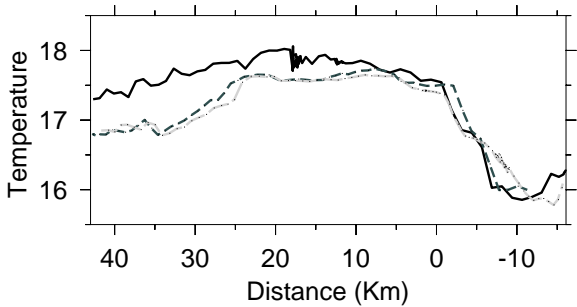

(d)

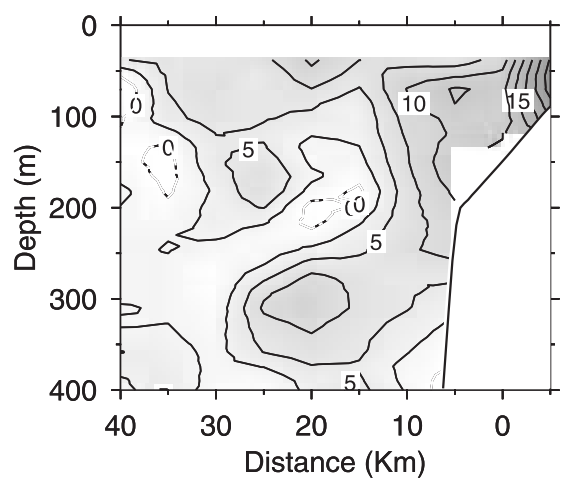

Fig. 7. Surface a) salinity and b) temperature coincident with the NB ADCP section averages (lighter line colour indicates later crossing) for transect $\mathrm{N}$ : c) across-shelf component (+ve onshore) and d) along-shelf component (+ve alongshore). The coast local direction is $7.1^{\circ} \mathrm{W}$.

(a)

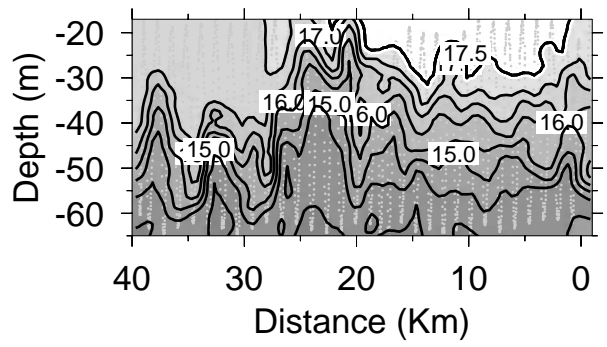

(b)

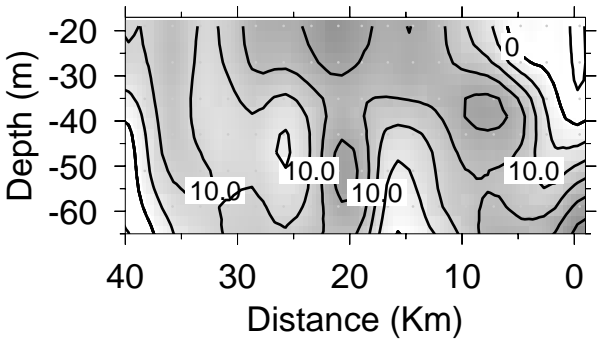

Fig. 8. Coincident $\mathrm{N}$ section of a) temperature from the UOR and b) along-shelf component (+ve alongshore) from the BB ADCP. The coast local direction is $7.1^{\circ} \mathrm{W}$.

\subsection{The North Coast}

The data presented here were collected between 25 October and 6 November, during a period of variable winds (Fig. 3a-b) but strong and steady poleward flow off both the west coast and Cape Finisterre (Fig. 3c-d), with surface values $>15 \mathrm{cms}^{-1}$ at the buoy locations.

The first CTD sampling of transect PW1 (the easternmost transect in the north coast) on 25-26 October was undertaken before the warm core of the 
poleward flow reached the site (Fig 2c). The surface salinity (Fig. 9a) showed in only one repeat any evidence of near-shore fresher water, while the surface temperature transect (Fig. 9b) showed a weaker maximum of width $50 \mathrm{~km}$ in mid-section. The sub-surface maximum of salinity at 100m (Fig. 9c) associated with the poleward flow in the west coast was again present, albeit weaker (35.8psu instead of $35.9 \mathrm{psu}$ in the western coast) and closer to the shelf edge (within 10km). The isohalines (and isopycnals - not shown) deepened over the upper slope edge, as in previous transects $\mathrm{P}$ and $\mathrm{N}$, consistent with poleward flow. The salinity maximum ( $>35.7 \mathrm{psu}$ ) extended offshore $70 \mathrm{~km}$ and down to $300 \mathrm{~m}$ depth. Transects in the west coast did not reach as far offshore but it is likely a similar distribution, with a clear offshore limit, was present. At the deepest levels $(>400 \mathrm{~m})$ salinity was relatively high nearshore, but decreased to $<35.6 \mathrm{psu}$ at $65 \mathrm{~km}$ offshore. The lowest salinity $(<35.3 \mathrm{psu})$ was measured in the near-surface layer above $25-30 \mathrm{~m}$, between the shelf-break and $55 \mathrm{~km}$ offshore. This was probably in response to the brief upwelling favourable winds on 25-26 October and represents water from the Rias advected offshore.

In this section, warmer surface temperatures were associated with low salinity at the surface. The sub-surface salinity maximum corresponded to locally warmer waters (seen as deepening of the $12^{\circ} \mathrm{C}$ isotherm) and reduced mixed layer depth in agreement with its southern origin where wind mixing is weaker and near surface stratification stronger. The thermocline deepened sharply at the shelf edge, parallelling the 37.5 isohaline to reach the bottom at $-15 \mathrm{~km}$ inshore of the break. Isotherms also turned sharply downward nearer to shore. At the deepest levels, the offshore low salinity waters were colder than the saltier slope waters, which represent the shallowest levels of Mediterranean water influence.

High surface fluorescence levels were measured across the entire section except inshore of $-10 \mathrm{~km}$, where the water was vertically mixed. No sign of reduced surface fluorescence levels was found in relation to the poleward intrusion in contrast to all west coast sections.

The vertical density distribution strongly resembled the temperature structure with deeper mixed layers at either side of the sub-surface maximum salinity and steep deepening of the isopycnals at the shelf edge indicative of geostrophic poleward flow.

The evolution of surface salinity and temperature during the multiple realisations of section PW1 is shown in Fig. 9a-b. The weekly composite of SST around the time of the first two crossings (Fig. 2b) shows a band of cold water at the location of transect PW1, remnant of previous upwelling events, and indeed a band of cold and salty water was seen in the in situ data over the shelf (Fig. 9a-b). The coastal band increased in temperature inshore which supports the idea of inactive upwelling. By the third crossing, fresher 


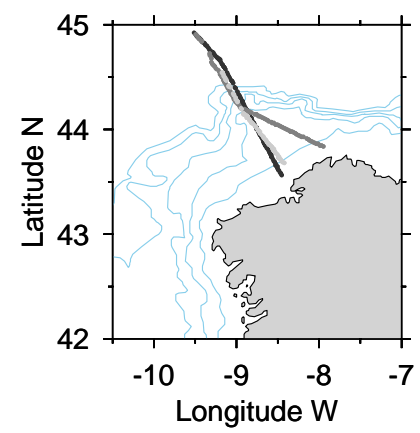

(a)

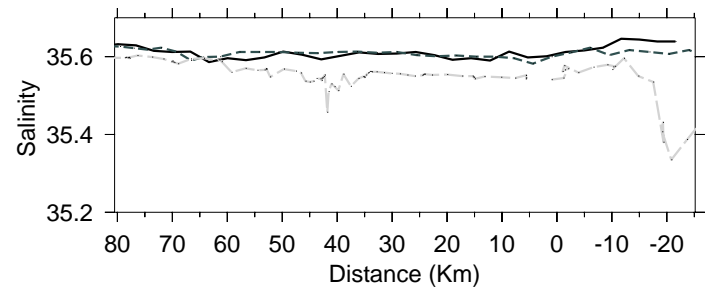

(c)

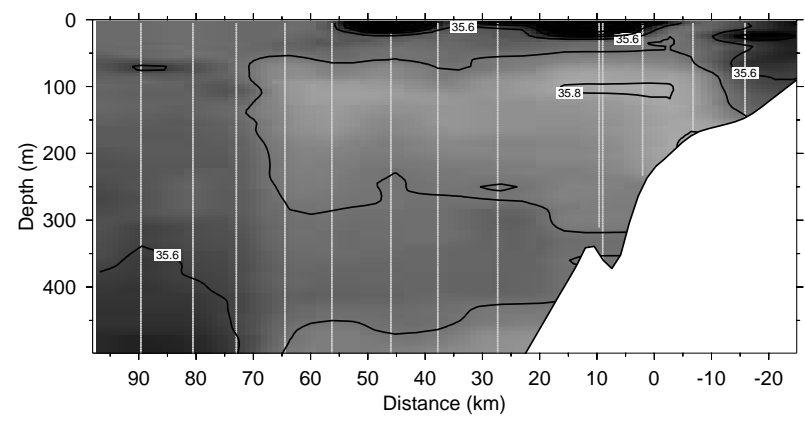

(b)

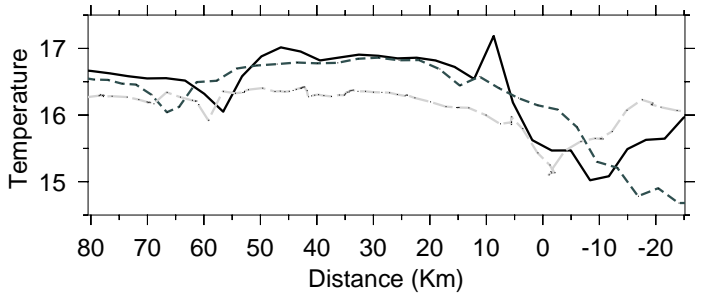

(d)

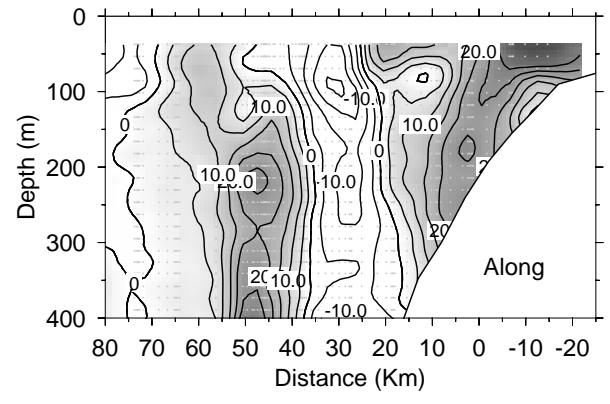

Fig. 9. Location of surface realisations of PW1 transect (21-26 October, lighter line colour indicates later crossing) with a) salinity and b) temperature, and concurrent vertical sections of c) salinity and d)rotated velocity component across shelf (25-26 October). The coast local direction is $62^{\circ} \mathrm{E}$.

and warmer water (salinity $<35.4 \mathrm{psu}$, temperature $>16^{\circ} \mathrm{C}$ ) was established nearshore (20km inshore of the shelf edge). Surface temperature and salinity decreased overall. Changes in the velocity sections (not shown) suggest an increase in poleward flow nearshore with flows reaching $30 \mathrm{cms}^{-1}$ on the last crossing (Fig. 9d). Much of the variability present in the sections is tidal, but the strength of the flow and its similarities to the hydrography (Fig. 9) give support to the presence of a largely barotropic coastal poleward flow.

The next three transects PW2-4, were done consecutively towards Cape Finisterre (Fig. 1b) in the presence of downwelling favourable winds (Fig. 3). The surface transects consistently displayed uniform salinity offshore $(\sim$ $35.6 \mathrm{psu}$ ), a weak surface maximum between 10 and $30 \mathrm{~km}$ off the shelf, and a minimum of $34.4 \mathrm{psu}$ on the shelf (Fig.10a). The temperature field was characterised by an across-shore gradient with maximum temperatures 
(a)

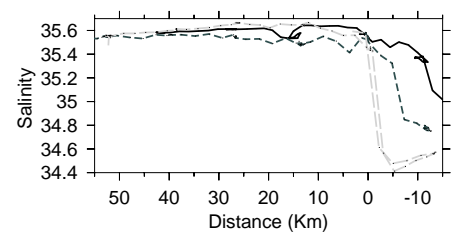

(c)

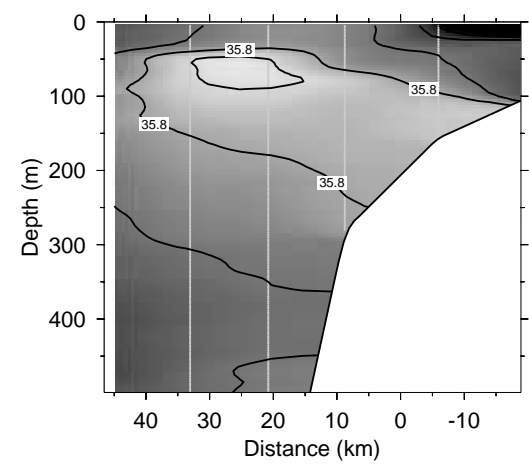

(b)



(d)



(e)

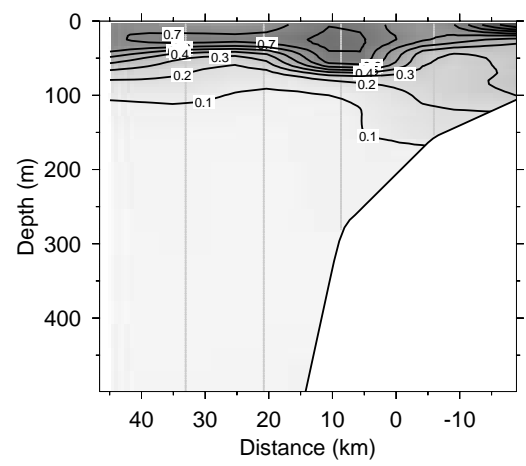

(f)

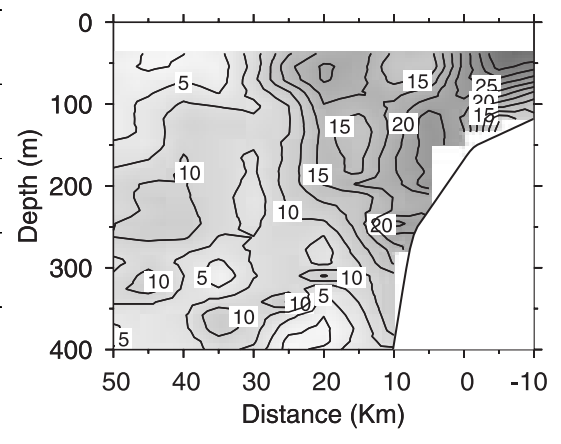

Fig. 10. Underway transects PW2-4 (31 Oct-2 Nov) for a) surface salinity and b)surface temperature (lighter line colour indicates later crossing). Vertical sections of transect PW4 (2 November) for c) salinity, d) density, e) fluorescence and f) ADCP section average of transects PW2-PW4 along-shelf component (+ve) alongshore. The coast local direction is $62^{\circ} \mathrm{E}$.

nearshore (Figs. 10b) and no sign of a surface warm anomaly, in contrast to the situation found in the west coast.

The low salinity coastal band ( $5 \mathrm{~km}$ inshore of the shelf edge) was vertically homogeneous and extended to the bottom (down to $100 \mathrm{~m}$ ) at the common coastal station in the first two transects (not shown). It probably came from the three rivers that flow into the Ria of Betanzos (see Fig. 1). In transect PW4 a shallow, lower salinity, surface layer had formed in the upper $25 \mathrm{~m}$ (Fig. 10c). A gradual change in the sub-surface salinity maximum was seen in all transects. As the sections were sampled closer to Cape Finisterre the 
salinity maximum (delimited by the $35.7 \mathrm{psu}$ isohaline) broadened, deepened to $350 \mathrm{~m}$ depth near the slope, and broached the surface between 5 and $30 \mathrm{~km}$ off the shelf (Fig. 10c). It intersected the bottom $10 \mathrm{~km}$ either side of the shelf edge. The salinity maximum also increased in value to $>35.9 \mathrm{psu}$ towards Cape Finisterre shoaling from $100 \mathrm{~m}$ to $65 \mathrm{~m}$ at $30-20 \mathrm{~km}$ offshore.

The density structure (largely determined by the temperature field) of transects PW2-PW4 showed a weakening of the vertical gradient, seen as wider separation of isopycnals associated with the salinity maximum at $20-30 \mathrm{~km}$ off the shelf (e.g. Fig. 10d). Lower density was associated with the coastal freshwater band, as in section PW1. All transects suggested geostrophic poleward flow on the shelf and between 100-300m, at which depth the isopycnals deepened towards the slope (Fig. 10d). The chlorophyll fluorescence showed relatively high $(>0.7 \mathrm{~V})$ surface values along the entire extent of the sections, but was lower near Cape Finisterre (Fig. 10f). No significant sub-surface maximum was found in these sections.

The averaged velocity structure for transects PW2-PW4 (Fig. 10g) shows fundamental differences with the west coast transects. The across-shelf component (not shown) was offshore and weak almost everywhere $\left(<7.5 \mathrm{cms}^{-1}\right)$. The along-shelf component lacked the double core structure of the west coast. Instead, poleward flow was trapped over the slope and shelf in a wedge-like form. A strong baroclinic poleward jet $\left(>30 \mathrm{cms}^{-1}\right)$ was associated with the near-shore salinity front.

The last three days of the cruise were dedicated to a short Lagrangian experiment from 14:17 on 3 November to 11:27 on 6 November. A buoy drogued at $100 \mathrm{~m}$ with a cruciform sail was placed at the centre of the poleward flow $25 \mathrm{~km}$ off the shelf break and coincident with the offshore salinity maximum of transect PW3 (see Fig. 1b for the location of the CTD stations during the drift, $\mathrm{D}$ in the graph). The buoy was followed as it covered, approximately, the distance between transects PW3 and PW2. The averaged velocity profiles (Fig. 11a) show continuous poleward flow at all depths. Maximum discrepancy between the two instruments at their common depth range was less than $1 \mathrm{cms}^{-1}$ at depths of rapid change. The top $200 \mathrm{~m}$ corresponds to a strongly sheared poleward flow with an offshore tendency (with respect to the large scale shelf-edge orientation on the north coast). Maximum poleward flow $\left(15 \mathrm{cms}^{-1}\right)$ was measured below the thermocline (Fig. 11b) at $65 \mathrm{~m}$ decreasing almost linearly to $8 \mathrm{cms}^{-1}$ at $150 \mathrm{~m}$. Along-shelf poleward flow with near zero across-shelf component can be seen between $200 \mathrm{~m}$ and $400 \mathrm{~m}$. The along-shelf component decreased linearly from $9 \mathrm{cms}^{-1}$ to $7 \mathrm{cms}^{-1}$. Below that, between $400 \mathrm{~m}$ and $550 \mathrm{~m}$, weak, slightly offshore poleward flow was again present.

The top 200m in Fig. 11b encompasses the salinity maximum, which thickened 
(a)

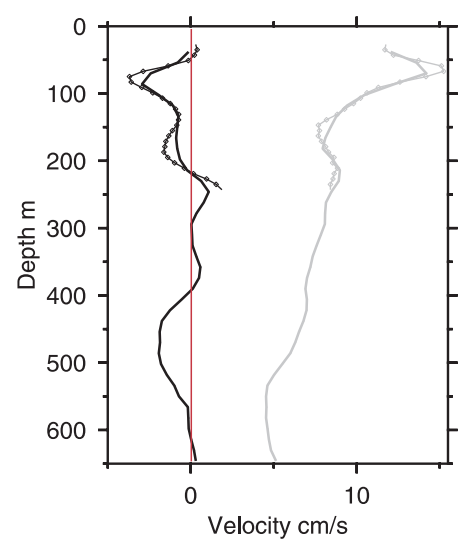

(b)

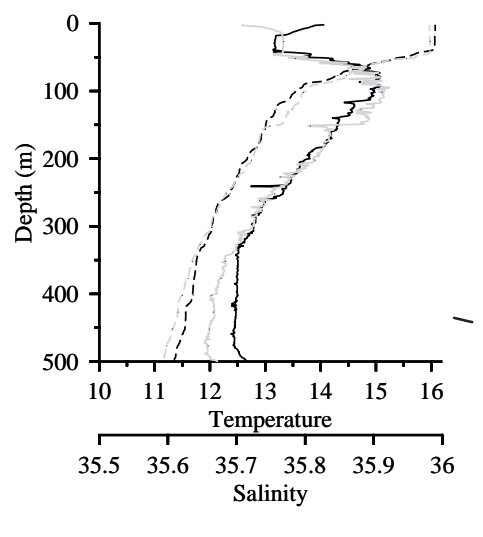

Fig. 11. a) Mean profile of along-shore (grey) and across-shore (black) components during the drift experiment on 3 14:17-6 11:27 November for both the BB (circles) and NB (solid) ADCP. The zero line is also shown. b) Temperature (dashed) and salinity (solid) for the first (black) and last (grey) CTD of the drift.

towards the end of the drift to reach $150 \mathrm{~m}$, where a sharp decrease in salinity (0.08psu) marks its lower limit. The waters beneath were characterised by a linearly decreasing salinity and temperature layer, which showed no change during the drift. Below 350m, the largest differences between the first and last CTD of the drift were measured, with both salinity and temperature decreasing.

\subsection{Watermass analysis}

$\mathrm{T} / \mathrm{S}$ characteristics for the cruise from surface to $500 \mathrm{~m}$ are summarized in Fig. 12. Selected casts from offshore positions outside the poleward flow (red and orange) represent the background oceanic conditions. They show an increased proportion of $\mathrm{ENAW}_{\mathrm{P}}$ with respect to the poleward flow casts (green and yellow) but no consistent differences can be drawn with respect to their latitude or proximity to the slope (the differences between the two northernmost offshore casts (red) were the largest). Above the central water definition lines, salinity was uniform and no sub-surface salinity maximum was found. The central waters $\mathrm{T} / \mathrm{S}$ relationships were shifted towards higher salinity or lower temperature compared to the ENAW reference line (Ríos et al., 1992), reflecting decadal changes in the $\mathrm{ENAW}_{\mathrm{P}}$ ventilation conditions (Pérez et al., 1995; Pollard et al., 1996). Evidence suggests that the changes are a large scale phenomenon (Huthnance et al., 2002). The poleward flow casts had a larger proportion of ENAW ${ }_{\mathrm{T}}$, as expected from the northward advection of ENAW $\mathrm{T}_{\mathrm{T}}$ of more southern origin, and a relatively well defined sub-surface salinity maximum on the $\mathrm{ENAW}_{\mathrm{T}}$ definition line. The sub-surface salinity 
(a)

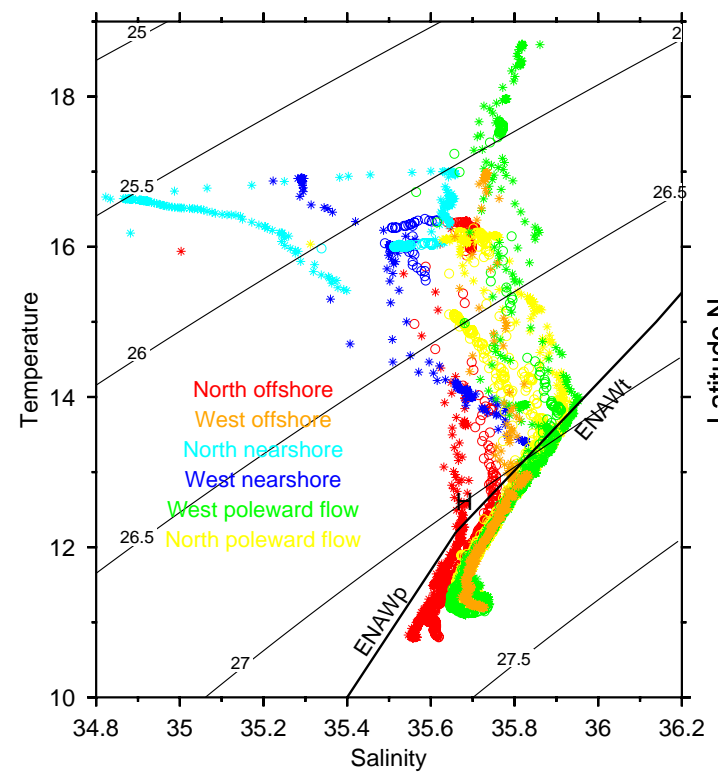

(b)

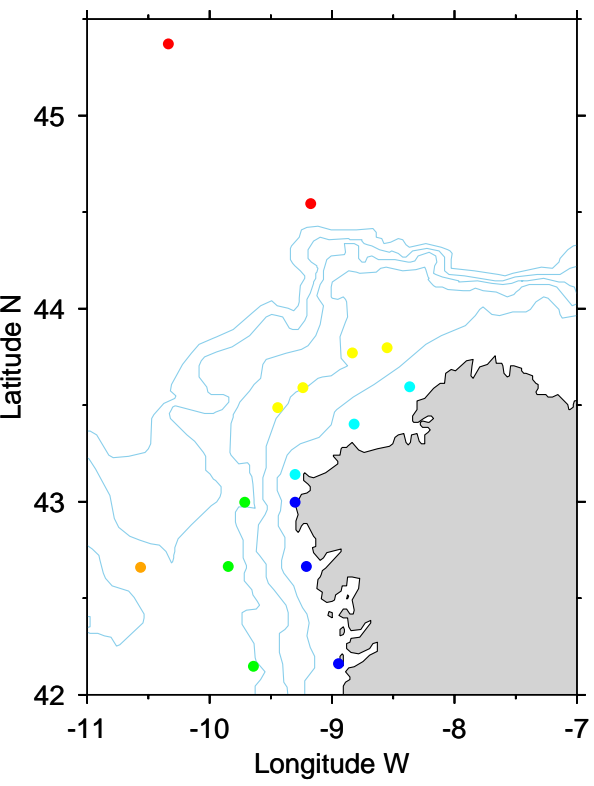

Fig. 12. a) T/S diagram between surface and 500m of representative sub-regions (offshore, coastal and poleward flow) encountered during the cruise on the west and north coasts. The regions are color coded as shown in the graph. Circles correspond to the northernmost CTD cast within each group and asterisks to the southernmost. b) Position of CTD casts with the same color code as a).

maximum shows similar range on both west and north coasts consistent with the developing poleward flow regime. On the north coast, higher values were encountered near Cape Finisterre decreasing polewards (eastwards) reflecting the southern source area at this developing stage. The nearshore stations (blue and cyan) showed influences of freshwater origin ranging from thin freshwater plumes to vertically mixed shelf-freshwater waters as described in previous sections.

\section{Discussion}

Slope poleward flows are ubiquitous along the entire western European shelf during at least part of the year. Remotely sensed SST (e.g. Pingree and LeCann, 1990), Lagrangian (e.g. Van Aken, 2002; Pingree, 1993) and modelling studies (e.g. Coelho et al., 2002; New et al., 2001), all suggest a continuous flow originating in the Portuguese coast and ending in the Norwegian coast. In the Iberian Peninsula, the poleward slope current has a strong seasonality with maximum flow in winter, reversing to southward flow during the summer (e.g. Haynes and Barton, 1990; Huthnance et al., 2002). North of Spain, seasonal variations in the flow decrease with latitude. Current reversals occur in February-April as far north as the Porcupine Bank, north 
of the Celtic Shelf (Pingree and LeCann, 1990), but in the Hebridean Shelf off Scotland, the flow only weakens during the summer and does not reverse (Souza et al., 2001). Maximum but more variable poleward flow occurs during winter in response to stronger winds.

In this article, data from the early stages of the slope current development in autumn have been presented. Favourable winds before the start of the cruise maintained weak upwelling in a nearshore band in the west coast and over a broader area off the north coast, as seen in SST images (Fig. 2a). Winds were downwelling favourable during the first half of the cruise and variable during the remainder of the cruise. Downwelling winds are expected to force poleward currents nearshore through momentum transfer and sea level elevation at the coast as a result of onshore Ekman transport near the surface. Vitorino et al. (2002) showed that surface and bottom currents at $41.3^{\circ} \mathrm{N}$ in mid-shelf were highly correlated to winds, which they lagged by $6 \mathrm{~h}$. The expected poleward wind driven currents on the west coast shelf were enhanced by the vertical mixing of the low salinity upper layer in the inner shelf. The increase in vertical mixing is evident in west coast transects $\mathrm{S}$ to $\mathrm{N}$ during the downwelling winds, where the surface layer depth increased from $25 \mathrm{~m}$ to $50 \mathrm{~m}$. On the north coast, the mixed layer reached $100 \mathrm{~m}$ thickness, and the thermocline, which lay between $50 \mathrm{~m}$ and $80 \mathrm{~m}$ depth seaward of the slope, intersected the upper slope topography as a bottom front, associated with poleward geostrophic flow. In response to both direct forcing associated with the downwelling winds and the geostrophic flow induced by wind mixing, poleward velocity increased over the shelf during the cruise. Velocity less than $2.5 \mathrm{cms}^{-1}$ in the first transect S (Fig. 5d) increased to values larger than $25 \mathrm{cms}^{-1}$ in the final one (Fig. 10g). Similar velocities were found by Vitorino et al. (2002), who measured northward velocities of about $20-30 \mathrm{cms}^{-1}$ on the northern Portuguese shelf during winter, and Haynes and Barton (1990), who measured northward velocities at $100 \mathrm{~m}$ depth of $\sim 20 \mathrm{cms}^{-1}$ at $42.8^{\circ} \mathrm{N}$ in September 1986.

The SST images at the time of the cruise showed a meridional SST gradient near $42^{\circ} \mathrm{N}$ which turned northwards at the slope in a warm tongue progressing northwards as in Haynes and Barton (1990). The meridional SST gradient near $42^{\circ} \mathrm{N}$ is a common feature of the early downwelling regime (Torres, 2003 ) and has an associated salinity gradient as shown here. Modelling studies of Dubert (1998) showed that poleward flowing surface warm intrusions are generated over 10 days during the adjustment of a meridional density gradient to the slope topography in western Iberia. Here similar results are apparent. With the onset of downwelling winds, cold water disappeared from the coast and the temperature front intersected the shelf-edge 2); within five days, a surface warm anomaly began to extend progressively northward from the front, serving as a surface tracer for the slope poleward flow during the cruise. Vertically averaged currents in the top $100 \mathrm{~m}$ show a close relationship to 
(a)

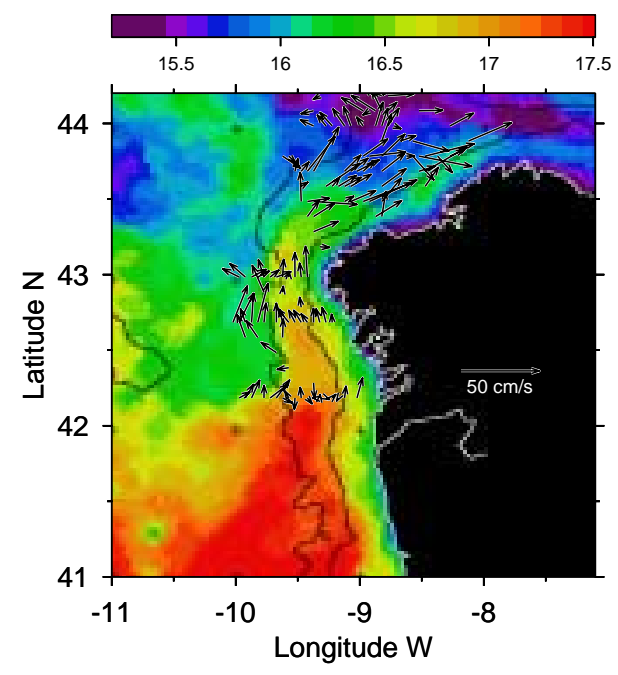

(b)

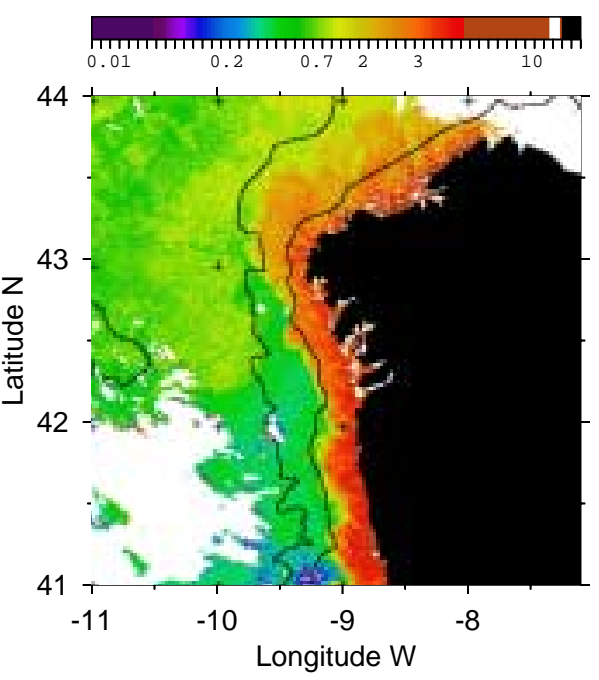

Fig. 13. a) Weekly SST composite (31 October-6 November 1999). Clouds and land are masked as black. Overlaid are the top 100m vertically averaged ADCP currents measured during the cruise. b) Chlorophyll derived values from SeaWiFS data for 8 November 1999. A low chlorophyll tongue can be seen parallel to the shelf edge on the west coast of Galicia failing to round Cape Finisterre. Clouds are masked white.

the warm surface anomaly (Fig. 13a). The detailed temperature structure at transect $\mathrm{N}$ showed the warm anomaly was restricted to the top $30 \mathrm{~m}$ and was approximately $20 \mathrm{~km}$ wide, close to the climatological Rossby radius of deformation calculated as $R^{\prime}=H N / f$, where $H$ is the thickness of the stratified upper layer, $N$ is the mean Brunt-Väisälä buoyancy frequency for that layer, and $f$ is the Coriolis parameter (Chelton et al., 1998). Raw velocity data indicated enhanced poleward flow in its offshore limit to at least $65 \mathrm{~m}$ depth related to down-sloping isotherms, an indication of geostrophic flow. The warm, low fluorescence surface anomaly was wider in the north coast with the expansion of the poleward flow onto the shelf as discussed previously. No indication of reduced fluorescence was apparent in the in situ data for the north coast, which suggests that either the initial narrow tongue did not reach further than Cape Finisterre or was mixed by the wind. The SeaWiFS image of the region after the cruise (9 November, Fig. 13b) shows a tongue of low estimated chlorophyll parallel to the west coast that failed to round Cape Finisterre. The SST images of the last portion of the cruise showed a narrow warm tongue along the north coast shelf edge and on the shelf rather than on the slope, being advected poleward by the wind driven and geostrophic flow described above.

The sub-surface salinity maximum near the slope has been used as a slope poleward flow tracer for some time now (e.g. Frouin et al., 1990; Hill and Mitchelson-Jacob, 1993; Souza et al., 2001), as it diminishes in value and deepens northwards. The vertical structure of the salinity found during the 


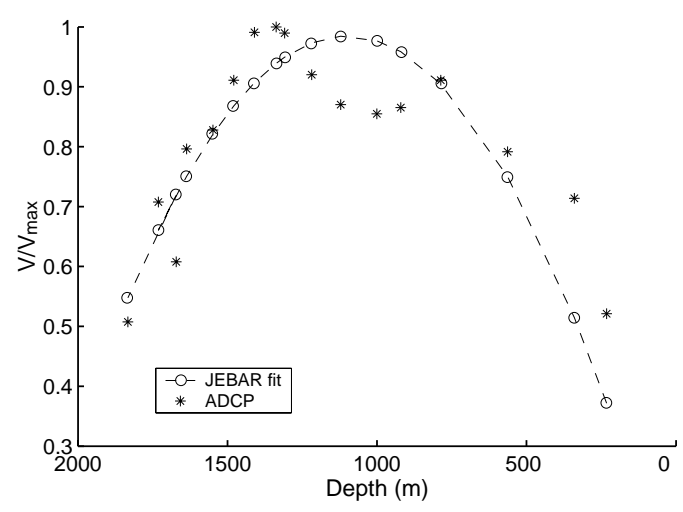

Fig. 14. Jebar fit following Eq. 2 to the depth-averaged velocity of all sections normalised by the section maximum velocity. No data shallower than $200 \mathrm{~m}$ is presented. The ADCP data was gridded every $2.5 \mathrm{Km}$ and $16 \mathrm{~m}$ in the horizontal and vertical.

present cruise resembles the data presented by Frouin et al. (1990), where, at $41.8^{\circ} \mathrm{N}$, a salinity maximum between $<35.8 \mathrm{psu}$ and $>35.9 \mathrm{psu}$ was located from $36 \mathrm{~km}$ to $55 \mathrm{~km}$ off the shelf edge. The Rossby radius of deformation ranged from $15 \mathrm{~km}$ to $20 \mathrm{~km}$ at the time. In the present data, a poleward flow maximum was generally associated with the offshore limit of the warm anomaly in the west coast and the sub-surface salinity maximum between $50 \mathrm{~m}$ and $100 \mathrm{~m}$ depth and $20-30 \mathrm{~km}$ off the shelf in the north coast. The Rossby radius of deformation ranged from $10-15 \mathrm{Km}$ for $\mathrm{H}=150 \mathrm{~m}$, to $25-30 \mathrm{Km}$ for $\mathrm{H}=500 \mathrm{~m}$. The latter values agreed with the climatological ones derived by Chelton et al. (1998). The sub-surface salinity maximum was better defined in the north coast, when surface current vectors from the buoys showed a steadier poleward current (Fig. 3c-d), and was located between 20-30Km off the shelf in agreement with the Rossby radius of deformation estimate. A good agreement between the sub-surface poleward velocity maximum location and $R^{\prime}$ was also found by Pierce et al. (2000) along the entire mid-latitude eastern boundary of the North Pacific from $34^{\circ} \mathrm{N}$ to $51^{\circ} \mathrm{N}$. Its width was also similar to $R^{\prime}$.

The averaging of the sections can not be expected to fully eliminate the oscillatory variability of tides and inertial waves but the agreement between maximum poleward flows in the averaged sections and the mean profile during the 3.5 day drift experiment gives support to the results. The mean along-shore profile during the drift showed poleward flow larger than $5 \mathrm{cms}^{-1}$ at all depths and suggests a continuous poleward flow from surface to MIW levels. A sub-surface maximum poleward flow was coincident with the sub-surface salinity maximum, although it could be a result of the non zero average of the surface intensified inertial currents. Northward advection of warmer and saltier waters from the west coast may explain the increased separation in isotherms at that level during the short drift experiment.

As mentioned in the introduction, JEBAR is a good candidate for forcing the 
slope current. It was introduced by Sarkisyan and Ivanov (1971), who derived a balance between the along-slope density gradient and surface slope in the absence of depth averaged cross-slope transport and friction as,

$$
\frac{\partial \eta}{\partial y}=-\frac{1 H \partial \rho}{2 \bar{\rho} \partial y}
$$

where $\eta$ is the surface height, $H$ is depth, and $\rho$ is density with $\bar{\rho}$ being a mean oceanic density reference. Equation 1 shows that the along-shore decline is greatest in deep water for a given meridional density gradient. Huthnance (1984) followed the argument further by deriving the cross-slope structure of a slope poleward flow forced by the interaction between the along-isobath density gradient and bathymetry along a narrow slope. The depth-averaged along-slope velocity component results from the balance of the longitudinal density gradient, the bottom topography and friction in the form:

$$
V(x)=\frac{g}{2 k \bar{\rho}} \frac{\partial \rho}{\partial y} h(x)(H-h(x))
$$

where $V$ is the along-slope velocity component, $k$ is a bottom drag coefficient, $g$ is the gravitational acceleration, $h(x)$ is the local depth and $H$ is the abyssal depth where the JEBAR tends to zero. Equation 2 can be used to diagnose the possibility of JEBAR forcing the poleward flow (Souza et al., 2001). The least square fit of the depth-averaged velocities from all sections normalised by the sectional maximum against $h(x)(H-h(x))$ (Eq. 2) showed a good fit (Fig. 14). The data covered the slope from the shelf-edge to $40 \mathrm{~km}$ offshore. The abyssal depth that optimised the fit was $2100 \mathrm{~m}$, which is deeper than the 1100-1600m found by Souza et al. (2001). From Eq. 2, a maximum velocity of $\sim 10 \mathrm{cms}^{-1}$ between 15-30km offshore, was obtained, which compared well with the measured depth-averaged velocity of $\sim 8 \mathrm{cms}^{-1}$. The gradient term $h / \rho \times \partial \rho / \partial y$ estimated from the least square fit was in the order of $\sim 10^{-7}$ in agreement with results from Souza et al. (2001) and Huthnance (1984). Numerical experiments from Dubert (1998) showed that a broad density gradient could indeed force a slope poleward flow and identified the JEBAR mechanism as the main forcing.

The presence and maintenance of the meridional density gradient in the western Iberian coast can be related to both the poleward cooling of the sea and features of the large scale circulation in the region. The large scale circulation offshore the Iberian Peninsula is weak; dominated by the southward flowing Portugal Current (Saunders, 1982) and eastward transport along the Portuguese-Spanish Atlantic coast. Eastward transport is more prominent south of $40^{\circ} \mathrm{N}$ and has been related to an eastward flowing branch of the Azores current (Käse and Siedler, 1982; Pollard and Pu, 1985) transporting ENAW $_{\mathrm{T}}$ (Ríos et al., 1992). At that latitude, both currents converge, helping 
to maintain and enhance the meridional density front. Evidence for this is somewhat circumstantial. Numerical experiments by Dubert (1998) with a broad density gradient similar to the one observed by Mazé et al. (1997) failed to reproduce the frontal instabilities and eddies observed in the region by $\mathrm{Vi}$ torino (1995). The associated geostrophic depth-integrated eastward transport was estimated by Mazé et al. (1997) as $2 \mathrm{~Sv}$ between $37.2^{\circ} \mathrm{N}$ and $43^{\circ} \mathrm{N}$. The sharper gradient sampled by Vitorino (1995), of the order of $100 \mathrm{~km}$ instead of the $600 \mathrm{~km}$ measured by Mazé et al. (1997), had similar associated eastward transport. Dubert (1998) found that the associated eddies provided another mechanism that helped maintain this smaller scale front, also suggested by Spall (1997). The associated transport entrains the poleward slope current and accounts for the increase proportion of $\mathrm{ENAW}_{\mathrm{T}}$ with respect to surrounding waters, also noted by Frouin et al. (1990). Numerical experiments with both the large and small scale meridional density gradients by Dubert (1998) produced a slope poleward flow provided the onshore transport was of similar magnitude.

The few transport estimates available for the slope poleward flow for the Iberian region have a large variability due in part to the different depths and offshore extent of integrations. Jorge da Silva (1996) in Huthnance et al. (2002) calculated integrated geostrophic transports from the shelf edge to the outer limit of the slope current down to $550 \mathrm{dbar}$ which ranged from $5.7 \mathrm{~Sv}$ at $37.25^{\circ} \mathrm{N}$ to 4.3 at $43^{\circ} \mathrm{N}$. Northward decrease in transport is consistent with topographic steering, including deflection around the Galician Bank (Coelho et al., 2002). Mean alongshore transport estimated from the present ADCP sections was smaller, $2 \pm 0.5 \mathrm{~Sv}$, calculated from the shelf edge to $40 \mathrm{~km}$ offshore and from $35 \mathrm{~m}$ to $500 \mathrm{~m}$ depth, possibly related to the early stages of the poleward flow development.

\section{Conclusions}

A combination of in situ and remotely sensed data have showed the first stages of development of the slope poleward flow in the Galician region.

- Poleward flow over the slope can be identified by a warm anomaly in SST, effectively acting as a tracer.

- Poleward flow extends onto the shelf and is intensified due to the wind induced sea level slope, mixing of the water column and formation of a bottom front, and direct transfer of momentum. Its associated mean poleward transport was $2 \pm 0.5 \mathrm{~Sv}$.

- Over the slope, poleward flow structure as depicted from the mean of the sections conforms to JEBAR forcing and is consistent within an order of magnitude with estimated values of the meridional density gradient. 
- Locations of the maximum sub-surface poleward flow and the associated salinity maximum were in agreement with the Rossby radius of deformation.

- The salinity maximum was better defined in the north coast at the time of steadier poleward flow reflecting the late stages of its development.

- Poleward flow was continuous to the maximum penetration depth of the ADCP, $650 \mathrm{~m}$, and could reach the level of MIW.

- Poleward flow at the MIW level and at the sub-surface maximum arise from different dynamical reasons but can form a continuous flow inducing topographic guidance of the surface flow.

- This becomes particularly relevant when the poleward flow reaches Cape Finisterre, where both continental slope and SST anomaly broaden.

\section{Acknowledgements}

Satellite images were received by the NERC Dundee Satellite Receiving Station, and processed by Peter Miller at the NERC Remote Sensing Group in Plymouth Marine Laboratories (http:www.npm.ac.ukrsdas). This work was supported by the European Union under MAST 3 programme, contract number MAS3-CT97-0076 OMEX and Plymouth Marine Laboratory. Part of the cruise was funded by the Spanish Marine Science and Technology Program (CYTMAR).

\section{References}

Arhan, M., A. C. D. Verdière, and L. Mémery (1994), The eastern boundary of the subtropical North Atlantic, Journal of Physical Oceanography, 24, 1295-1316.

Barton, E. D., M. E. Inall, T. J. Sherwin, and R. Torres (2001), Vertical structure, turbulent mixing and fluxes during lagrangian observations of an upwelling filament system off northwest Iberia, Progress in Oceanography, 51, 249-268.

Candela, J., R. C. Beardsley, and R. Limeburner (1992), Separation of tidal and subtidal currents in ship-mounted acoustic doppler current profiler observations, Journal of Geophysical Research, 97, 769-788.

Chelton, D. B., R. A. deSzoeke, M. G. Schlax, K. El Naggar, and N. Siwertz (1998), Geographical variability of the first-baroclinic Rossby radius of deformation, Journal of Physical Oceanography, 28, 433-460.

Coelho, H. S., R. J. J. Neves, M. White, P. C. Leitão, and A. J. Santos (2002), A model for ocean circulation on the Iberian coast, Journal of Marine Systems, 32, 153-179. 
Csanady, G. T. (1978), The arrested topographic wave, Journal of Physical Oceanography, 8, 47-62.

Dubert, J. (1998), Dynamique du système de courants vers le pôle au voisinage de la pente continentale à l'Ouest et au nord de la péninsule Ibérique, Ph.D. thesis, Université de Bretagne Occidentale, France.

Fanjul, E. A., B. P. Gómez, and I. R. Sánchez-Arévalo (1997), A description of the tides in the eastern North Atlantic, Progress in Oceanography, 40, $217-244$.

Fiúza, A. F. G., M. Hamann, I. Ambar, G. D. González, and J. M. Cabanas (1998), Water masses and their circulation in the western Iberian coastal ocean during may 1993, Deep-Sea Research I, 45, 1127-1160.

Frouin, R., A. Fiúza, I. Ambar, and T. J. Boyd (1990), Observations of a poleward surface current off the coasts of Portugal and Spain during the winter, Journal of Geophysical Research, 95, 679-691.

Godin, G. (1991), The analysis of tides and currents., in Tidal Hydrodynamics, edited by B. B. Parker, pp. 675-709, John Wiley \& Sons, New York.

Haynes, R., and E. D. Barton (1990), A poleward flow along the Atlantic coast of the Iberian Peninsula, Journal of Geophysical Research, 95, $11,425-11,141$.

Hill, A. E., and E. G. Mitchelson-Jacob (1993), Observations of a poleward-flowing saline core on the continental-slope west of Scotland, DeepSea Res. Part I-Oceanogr. Res. Pap., 40, 1521-1527.

Hill, A. E., B. M. Hickey, F. A. Shillington, P. T. Strub, K. H. Brink, E. D. Barton, and A. C. Thomas (1998), Eastern ocean boundaries coastal segment (e), in The Sea, Vol. 11, edited by K. H. Brink and A. R. Robinson, pp. 29-67, John Wiley \& Sons, Inc.

Howarth, M. J., and R. Proctor (1992), Ship ADCP measurements and tidal models of the North Sea, Continental Shelf Research, 12, 601-623.

Huthnance, J. M. (1984), Slope currents and "JEBAR", Journal of Physical Oceanography, 14, 795-810.

Huthnance, J. M. (1995), Circulation, exchange and water masses at the ocean margin: The role of physical processes at the shelf edge, Progress in Oceanography, 35, 353-431.

Huthnance, J. M., H. M. Van Aken, M. White, E. D. Barton, B. LeCann, E. F. Coelho, E. A. Fanjul, P. Miller, and J. Vitorino (2002), Ocean margin exchange- water flux estimates, Journal of Marine Systems, 32, 107-137.

Jorge da Silva, A. (1996), The slope current off the west Iberian coast in autumn, ICES C.M., 1996/S:35.

Käse, R. H., and G. Siedler (1982), Meandering of the subtropical front southeast of the azores, Nature, 300, 245-246.

Mazé, J. P., M. Arhan, and H. Mercier (1997), Volume budget of the eastern boundary layer off the Iberian peninsula, Deep-Sea Research I, 44, 1543-1574.

Miller, P. I., S. B. Groom, A. McManus, J. Selley, and N. Mironnet (1997), Panorama: A semi-automated AVHRR, and CZCS system for observation of 
coastal and ocean processes, in Proceedings of the Remote Sensing Society, Reading, September 1997, pp. 539-544.

Münchow, A. (2000), Detiding three-dimensional velocity survey data in coastal waters, Journal of Atmospheric and Oceanic Technology, 17, 736-749.

Neshyba, S. J., C. N. K. Mooers, R. L. Smith, and R. T. Barber (1989), Poleward flows along eastern boundaries, Springer-Verlag, New York.

New, A. L., S. Barnard, P. Herrmann, and J. M. Molines (2001), On the origin and pathway of the saline inflow to the Nordic seas: insights from models, Prog. Oceanogr., 48, 255-287.

Noble, M. A., and S. T. Ramp (2000), Subtidal currents over the central California slope: evidence for offshore veering of the undercurrent and for direct, wind-driven slope currents, Deep-Sea Research I, 47, 871-906.

Pérez, F. F., A. F. Ríos, B. A. King, and R. T. Pollard (1995), Decadal changes of the $\theta$-s relationship of the Eastern North Atlantic Central Water, DeepSea Research I, 42, 1849-1864.

Pierce, S. D., R. L. Smith, P. M. Kosro, J. A. Barth, and C. D. Wilson (2000), Continuity of the poleward undercurrent along the eastern boundary of the mid-latitude north pacific, Deep-Sea Res. Part II-Top. Stud. Oceanogr., 47, 811-829.

Pingree, R. D. (1993), Flow of surface waters to the west of the british isles and in the bay of biscay, Deep-Sea Research I, 40, 369-388.

Pingree, R. D., and B. LeCann (1990), Structure, strength and seasonality of the slope currents in the bay of biscay region, Journal of the Marine Biological Association of the U. K., 70, 857-885.

Pollard, R. T., and S. Pu (1985), Structure and circulation of the upper Atlantic ocean northeast of the Azores, Progress in Oceanography, 14, 443-462.

Pollard, R. T., M. J. Griffiths, S. A. Cunningham, J. F. Read, F. F. Pérez, and A. F. Ríos (1996), Vivaldi 1991 - A study of the formation, circulation and ventilation of Eastern North Atlantic Central Water., Progress in Oceanography, 37, 167-192.

Ríos, A. F., F. F. Pérez, and F. Fraga (1992), Water masses in upper and middle north Atlantic ocean east of the Azores, Deep-Sea Research I, 39, 645-658.

Sarkisyan, A. S., and V. F. Ivanov (1971), The combined effect of baroclinicity and bottom relief as an important factor in the dynamics of ocean currents, Izv. Acad. Sci. USSR, Atmos. Oceanic Phys. (AGU translation), pp. 173-188.

Saunders, P. M. (1982), Circulation in the eastern north Atlantic, Journal of Marine Research, 40, 641-657.

Souza, A. J., J. H. Simpson, M. Harikrishnan, and J. Malarkey (2001), Flow structure and seasonality in the Hebridean slope current, Oceanol. Acta, 24, S63-S76.

Spall, M. A. (1997), Baroclinic jets in confluent flow, Journal of Physical 
Oceanography, 27, 1054-1071.

Torres, R., and E. D. Barton (1999), Charles darwin CD114 cruise report: Acoustic doppler current fields, Tech. rep., University of Wales, Bangor.

Torres, R., E. D. Barton, P. Miller, and E. Fanjul (2003), Spatial patterns of wind and sea surface temperature in the galician upwelling region, Journal of Geophysical Research, 108(C4), doi:10.1029/2002JC001361.

Trowbridge, J. H., D. C. Chapman, and J. Candela (1998), Topographic effects, straits and the bottom boundary layer, in The Sea, Vol. 10, edited by K. H. Brink and A. R. Robinson, pp. 63-88, John Wiley \& Sons, Inc.

Van Aken, H. M. (2002), Surface currents in the Bay of Biscay as observed with drifters between 1995 and 1999, Deep-Sea Res. Part I-Oceanogr. Res. Pap., 49, 1071-1086.

Vitorino, J., A. Oliveira, J. M. Jouanneau, and T. Drago (2002), Winter dynamics on the northern Portuguese shelf. part 1: physical processes, Progress in Oceanography, 52, 129-153.

Vitorino, J. P. N. (1995), Resultados do cruceiro CECIR XVII, Tech. rep., Instituto Hidrográfico de Portugal.

Wang, D. P. (1982), Effects of continental slope on mean shelf circulation, Journal of Physical Oceanography, 12, 1524-1526.

Wang, D. P. (1997), Effects of small-scale wind on coastal upwelling with application to point conception, Journal of Geophysical Research, 102, $15,555-15,566$. 